\title{
An Analysis of the Long-Run Performance IPOs and Effects in the Kenyan Stock Market
}

\author{
Sarah Kinya Mburugu \\ Post graduate student, School of Business, University of Nairobi \\ sara.mburugu@gmail.com
}

Keywords: Long-Run Performance, IPOs, Kenyan Stock Market, Listed companies, Nairobi Securities Exchange

\begin{abstract}
Listing of a company in the securities exchange has been observed to be followed by underpricing in the first day and long term period of underperformance in terms of pricing in the subsequent days. Consequently, there has been a considerable curiosity from stakeholders, investors and academics to comprehend the assessments of why companies go public and the issues surrounding the short and long-run performance of newly issued equities. Underpricing is necessary to induce uninformed investors to participate in IPO offering when faced with adverse selection from informed investors. This often leads to first day price not reflecting a fair value of the IPO. The objective of the study was to determine the long-run performance IPOs and effects in the Kenyan stock market for the period 2007-2014. A descriptive survey research design was employed in the study. The population of the study encompassed all the 64 listed companies at the NSE as at 2016. The study employed a non-probability purposive sampling technique. Data collected for this study was secondary data obtained from NSE website, NSE price lists and the Central Bank of Kenya website for the period 2007 to 2014. The data obtained was analyzed using Statistical Package for Social Science (SPSS). Mean Average Buy and Hold Returns (MABHR), Abnormal Returns (AR) and Cumulative Abnormal Returns (CAR) were used to calculate the performance of the stocks. T-statistic for CAR was computed to the test for its significance. T-test was conducted at 95\% confidence level to find if MABHR and CAR were statistically significant after IPOs announcement.
\end{abstract}

\section{Introduction}

Initial Public Offerings (IPOs) are one of the most captivating and studied proceedings in the world of finance, and the pricing behavior of IPOs has been one of the great mysteries of modern corporate finance [1]. [2] assert that characteristically, IPOs are chief focus, more so if they are listed alone, they can rouse the whole market. They further add that IPOs cannot be disregarded in emerging markets. [3] suggest in their study that an IPO can escalate media publicity or firm's stand in going public.

[4] assert that IPOs first trading is so inconsistent, that it is not possible to analyze the trend of stock performance. Further, they are predictable and thus giving no particular entity the benefit of abnormal strategy. [5] in ratifying the efficient markets hypothesis affirms that IPOs and stock matters are established by markets that are efficient and cannot thus have instances of abnormal returns. Nevertheless, [6] presents a deviancy of the IPO prices from projected figures thus revealing that the markets are inefficient whereas evidence of abnormal returns is inevitable.

Initial Public Offer (IPO) is the first sale of stock by a private company to the public. It involves a process where companies resolve to modification from a private company to a public company and in the process, sell the stocks in the company [7]. A company that desires to initiate an IPO in Kenya has to first obtain the authorization from the Capital Markets Authority. The Authority (CMA), in considering an IPO proposal, takes into account compliance with the legal and regulatory framework by the company undertaking the IPO [8]. One of the typical and practical methods to measure an IPO's success that eschews the goal of a huge first day leap in share price is viewed more invaluable metric because it takes into account a company's longer-term competitiveness and the degree to which both new and existing shareholders are fairly compensated [9]. 
The relationship between IPO performance and stock prices performance is investigated by [10] and conclude that in the long-run, big firms with lower ownership retention provide lower returns after the long-term regression equations. [11] did a study on the Hong Kong stock market for IPO's within 1993-1997. They stated that demand of investors for IPO's is certainly linked to the initial returns of these companies. They further established that there is a solid link concerning investor demand for IPO's and the long-run post-issue performance of IPOs. The revenues of the first trading day indicate that the IPO's with high investor demand are significantly underpriced while the IPO`s with low investor demand are overpriced.

[12] in the prospects theory stated that people make decisions based on the potential value of losses and gains rather than the final outcome and that people assess such losses and gains using certain influences. [13] submitted a different description for the long-run underperformance of IPO stocks using prospect theory. They assumed that the decision maker's initial estimation principles are reflected in the mean of the indicative price range reported in the issuing firm's IPO registration statement.

In Kenya, there is growing interest in investing in equities, especially shares, at the Nairobi Securities Exchange (NSE). However, selected IPOs have proved to be a risky investment [14]. Investors find it hard predicting what the stock will do on its initial day of trading and in the near future because there is often no information to evaluate the company. In addition, most IPOs are of companies going through a transitory growth period, that exhibit high uncertainty with respect to their future values.

An ideal market is one which prices provide accurate signals for resource allocation, that is, a market in which firms can make production-investment decisions and investors can choose among securities that represent ownership of firms' activities under the assumption that prices fully reflect all available information [15]. According to [16], the Nairobi Securities Exchange has few IPOs compared to developed markets. The IPOs have been highly over-subscribed with Barclays bank of Kenya detailing an excessive of $613 \%$, Eveready at over $800 \%$, and Safaricom the biggest offer in the region at $382 \%$. In all the oversubscribed offers, so much money was left "on the table" and these results into hefty refunds to subscribers. On $16^{\text {th }}$ July 2015, the NSE registered the Settlement Guarantee Fund (SGF); a fund established to strengthen the financial integrity of the derivatives market and to ensure settlement of transactions in the remote case of default by a clearing member. On the same date, the NSE set up the Investor Protection Fund (IPF); a fund created to satisfy potential claims of clients against trading members should adverse events occur (NSE, 2015). Foregoing studies on long run performance of IPOs at the NSE by [17], [18] and [19] have indicated that IPO firms severely underperform their comparable benchmarks.

\subsection{Research Problem}

It has been observed that the moment a company is listed in the securities exchange, underpricing is witnessed in the first day, followed by long term period of underperformance in terms of pricing in the subsequent days. Consequently, there has been a considerable curiosity from stakeholders, investors and academics to comprehend the assessments of why companies go public and the issues surrounding the short and long-run performance of newly issued equities. According to [20], underpricing is necessary to induce uninformed investors to participate in IPO offering when faced with adverse selection from informed investors. This often leads to first day price not reflecting a fair value of the IPO.

[21] studied pricing and performance of IPOs and [22] examined the short-run price performance of an IPO. [23], [24] and [25] posit that a long-term investor who buys shares of a firm right after it goes public may realize abnormal negative risk-adjusted returns. [24] finds a positive relation between the initial day return and aftermarket underperformance. [26] surveyed short-run underpricing and its characteristics in Chinese IPO markets and found that Chinese IPO underpricing is primarily explained by the inequality of supply and demand caused by the quota system and the high proportion of uninformed individual investors. [27] examine effects of underpricing and share retention on IPO aftermarket liquidity. [28] point out that there is no 
single dominant theoretical cause for underpricing. [28] show that an IPO underpricing is significantly related to the Price/Equity ratio differential, capital rise, offer price and the 30-day cumulative pre-market return before listing IPOs. Research by [29] shows that ex ante financial strength (based on the Altman Z-score) has a significant negative effect on short-run underpricing.

With regards to the IPOs focuses in Kenya, a number of studies have been done, such as [30] the effect of initial public offerings on the stock returns of companies listed at the Nairobi Securities Exchange, [7] on a comparative evaluation of the performance of IPOs of private and state-owned companies, [31] on the relative importance of the factors influencing decision making in IPOs in Kenya, [32] on the determinants of the success of IPOs among listed companies, Rajab (2009) on the effect of IPOs on the performance of other stocks, [16] on investor's demand for IPOs and 1st day performance and [33] on pricing and performance of IPOs. Most of these studies have focused on IPO performance of companies listed on NSE, private companies, or of other stocks. [34] studied on medium term performance of IPOs, whereas this study is focusing on the performance and long run effects of IPOs in the Kenyan market.

Mostly, the studies done so far determined a long-run underperformance. IPOs at the NSE presented noteworthy excess returns in the three years following the offer, with highest returns on the first year and a decrease in the second and the third year, then estimated the market drive thereafter. This study analyzed effects of IPOs on long-run performance in the first five years of trading to establish whether our study results are similar to those done on the long-run performance of IPOs both locally and internationally. The monthly long-run studies for five years have not been conducted in Kenya's NSE hence forming the research gap for the study. Furthermore, because the study variations that have been done in the past and the information asymmetry, this study attempts to show whether these factors stated in the various studies are indeed the long run effects of IPOs performances. The study therefore, sought to answer the following research questions: What determines the performance of IPO in the Kenyan Market? What has been the effect of IPOs over the past five years in the Kenyan stock market?

\subsection{Objectives of the Study}

To determine the long-run performance IPOs and effects in the Kenyan stock market.

\section{Literature Review}

\subsection{Theoretical Foundation}

Various theories were proposed to explain the phenomenon of the long-run performance of IPOs.

\subsubsection{Efficient Market Hypothesis}

[4] asserted in his study, that in a liquid market, security prices fully reflect all available information. Therefore, in an efficient market, competition among the many intelligent participants leads to a situation where, at any point in time, prices of individual securities already reflect all available information. [35] articulate that a security market is largely described as efficient on condition that the prices of securities traded in the market act as though they fully reflect all available information, these prices react instantaneously, or nearly so and in an unbiased fashion to new information. [36] however, discredits the EMH belief that all market participants have the same expectations of future security prices as this will kill trade, and its implication that buy and hold strategy is as good as any other trading strategy gives no scope for entrepreneurial trading.

Efficient Market Hypothesis, therefore, suggests that essential and technical security analysis is not sensible hence, supporting a passive portfolio management [37]. Construing that, in an efficient market at any point in time, the actual price of a security will be a good approximation of its intrinsic value. Thus for this study, the theory suggests that the performance of an initial price offer will influence the stock price in the market at any time, for the reason that there is information asymmetry. 


\subsubsection{Random Walk Theory}

The random walk theory, which is consistent with the efficient-market hypothesis, is a financial theory stating that stock market prices evolve according to a random walk and thus cannot be predicted [4]. Although uncertainty concerning intrinsic value will remain, actual prices of securities will wander randomly about the intrinsic value. [3] asserted that a technical trader who relies exclusively upon past price trends to predict future price changes cannot realize greater profits than those who buy and hold. Differing to studies that support random walk hypothesis, [38], presented a study and tests supporting the existence of trends in the stock markets and those stock markets are somewhat predictable. The theory, therefore, implies that, statistically, stock price fluctuations are independent over time. For investors, economists and financial theorists, technical or charting trading rules will not result in average profit that is greater than that obtainable with a simple buy and hold strategy [3]. The theory hence implies that, statistically, stock price fluctuations are independent over time. Relative to our study, the theory supposes that performance of IPOs affects stock prices but not the variations of the stock exchange in the long run operations.

\subsubsection{Prospects Theory}

[12] established the prospects theory. They stated that people make decisions based on the potential value of losses and gains rather than the final outcome and that people evaluate such losses and gains using certain heuristics. [13] submitted a diverse illustration for the long-run underperformance of IPO stocks using prospect theory. According to this theory, undefined effects enter an investor's utility function through a nonlinear transformation of their probabilities. Small probability measures are given more weight than in expected utility theory, whereas median and large probability events are given less weight. IPO stocks have more extreme positive returns; hence they are valued more in prospect theory than in expected utility theory. They tested the theory with [24] IPO sample.

[39] adopted the behavioral perspective in their elaboration of a prospect theory model of complacency about banks 'leaving money on the table' among decision-makers at firms involved in IPOs. They assumed that the decision maker's initial estimation principles are reflected in the mean of the indicative price range reported in the issuing firm's IPO registration statement. [40] also derived a behavioral measure of the IPO decision maker's satisfaction with the underwriter's performance based on [39] prospect theory of IPO underpricing. They assessed the plausibility of this measure by studying its power to explain the decision maker's subsequent choices. This endeavors towards describing the performance of IPOs in the long run.

\subsubsection{Winners Theory}

This model is based on a horizontal asymmetry of information, which exists between different groups of investors [20]. In this model, Rock applies the concept of the winner's curse to the new issues market. For that reason, the common explanation for the abnormal first-day price behavior is the "winner's curse in which Rock uses the assumption that some investors have better information available about the value of the firm than others. In this model, the true value of the IPO share, 'v', is unknown. The issuer pre-selects an offer price ' $p$ ' and an offer quantity, ' $Z$ '. There are two states of the world, i.e., $\mathrm{p}<\mathrm{v}$ (underpricing) and $\mathrm{p}>\mathrm{v}$ (overpricing). [9] notes that the most cited in IPO underprice literature are the result of winner's curse. [9] notes that the [20] model, winner's curse is an application of [41] lemon problem. It explained that the IPO market consists of two groups of investors: the informed investors who have the superior knowledge on the true value of the issues and uninformed investors, who lack the special knowledge to correctly value, the issue.

Due to this information asymmetry, informed investors are knowledgeable about the future prospects of the shares being sold and will only attempt to buy when the issue is underpriced. Uninformed investors, on the other hand, do not know which issues are underpriced or overpriced and therefore do not discriminate between issues when they apply for IPOs. 
Therefore, uninformed investors who are aware of the winner's curse and have little knowledge of the IPO will generally avoid subscribing to the bad issue. Due to this contrary assortment problem, the uninformed investors will exit the market unless IPOs are sufficiently underpriced on average to compensate them for their informational handicap. The Rock model does not address the question of why investment banks might want to tempt uninformed investors to remain in the market. However, [42] this phenomenon can be understood by examining the incentives of the investment banks. Investment banks are recurrence companies in the IPO market. Further, the investment banking industry is oligopolistic and each knows that it can significantly affect the IPO market through its actions. If IPOs are not underpriced, uninformed investors make regular losses and ultimately exit the IPO market. In these circumstances, only well-versed investors endure in the marketplace. This moves to explain the effects of the IPOs on the stock market as is sought by this study.

\subsection{Determinants of Stock Price Performance}

\subsubsection{Size of Offer}

The size of the offer is measured by multiplying the offering price and a number of shares offered. [43] in their study on South African IPOs presented that offer size has an extensive negative effect on the extent of underpricing. This is because low shares, according to their research are viewed as a high risk. A study by [44] determined a progressive link between the size of an IPO and the price of the stock. On the contrary, [45] found an adverse correlation between the size of an IPO and the price of the stock. [46] concluded that the size of the offer is inversely proportional to the scale of underpricing. They argued in their study that the size of the issue and underpricing of IPOs is linked to substitution for disproportionate statistics.

\subsubsection{Size of Firm}

[47] studied size of the firm as a variable that affects IPO underpricing in Ghana and Nigeria over 1990 and 2006. Resulting from the regular empirics in explaining opening irregular returns in IPOs they assessed multiple regression models and found that underpricing is positively correlated to firm size. According to [48], the size of the IPO firm has significant inference for pricing as it is a significant determinant of stability of the firm. [49] did a study on Malaysian IPOs and found that initial return was driven by the size of the firm. His study examined a sample of 277 Malaysian IPOs from January 2004 to December 2010 and found that the size of the firm was a determinant of IPO performance. The result indicated that the average initial return of IPOs listed on the Malaysian alternative stock market is significantly higher than the average of those IPOs listed on the main market (a proxy for big sized firms) an indication that "size effect" plays an important role in explaining the IPOs performances in Malaysian IPOs.

\subsubsection{Subscription Rate}

Subscription level of IPOs represents the total demand of the issue generated in the stock market. The demand for the IPO is measured by the subscription rate. It is calculated by dividing total demand of the issue by total offer size. [50] found that there is an affirmative connection between investor demand and first-day performance. From their study [44] assert, there is a positive relationship between subscription level and raw returns of IPOs. [51] did a study to measure the relationship between subscription and underpricing and found an assured connection. The degree of pricing depends on statistics heterogeneity among investors which upsurge with the demand for the firm's shares [20]. This was supported by [52\} who found a positive relation between underpricing and oversubscription.

\subsubsection{Age of the Firm}

[53] found that the age of the firm is paramount in explaining the performance of IPOs after studying 2,292 IPOs issued in the US between 1979 and 1991. They established that older firms have longer operating histories and face less uncertainty. This conclusion suggested that older firms 
have a lower degree of information asymmetry than younger firms, thus affecting the price and performance of their IPOs. [54] resonated on the same and contended that younger firms have shorter operating history and are subject to a great deal of uncertainty.

\subsubsection{Investor Sentiment}

According to a study by [55], investor sentiment is a certainty in view of forthcoming cash flow and investment risks that are not substantiated by present probabilities. Behavioral finance literature points to the fact that trade clatter is the cause of investor sentiments thus making them suffer psychological bias whereas rational expectation theory cannot explain their trading behavior. According to [56], behavioral biases have become increasingly prominent in explaining asset pricing that is inconsistent with a justified decision-making framework. [57] contended that investors are eager to pay a premium in excess of their rational belief if the sentiment is biased towards newly issued stocks. Needless optimism pushes asset values above the first principles [58].

\subsubsection{Conceptual Framework}

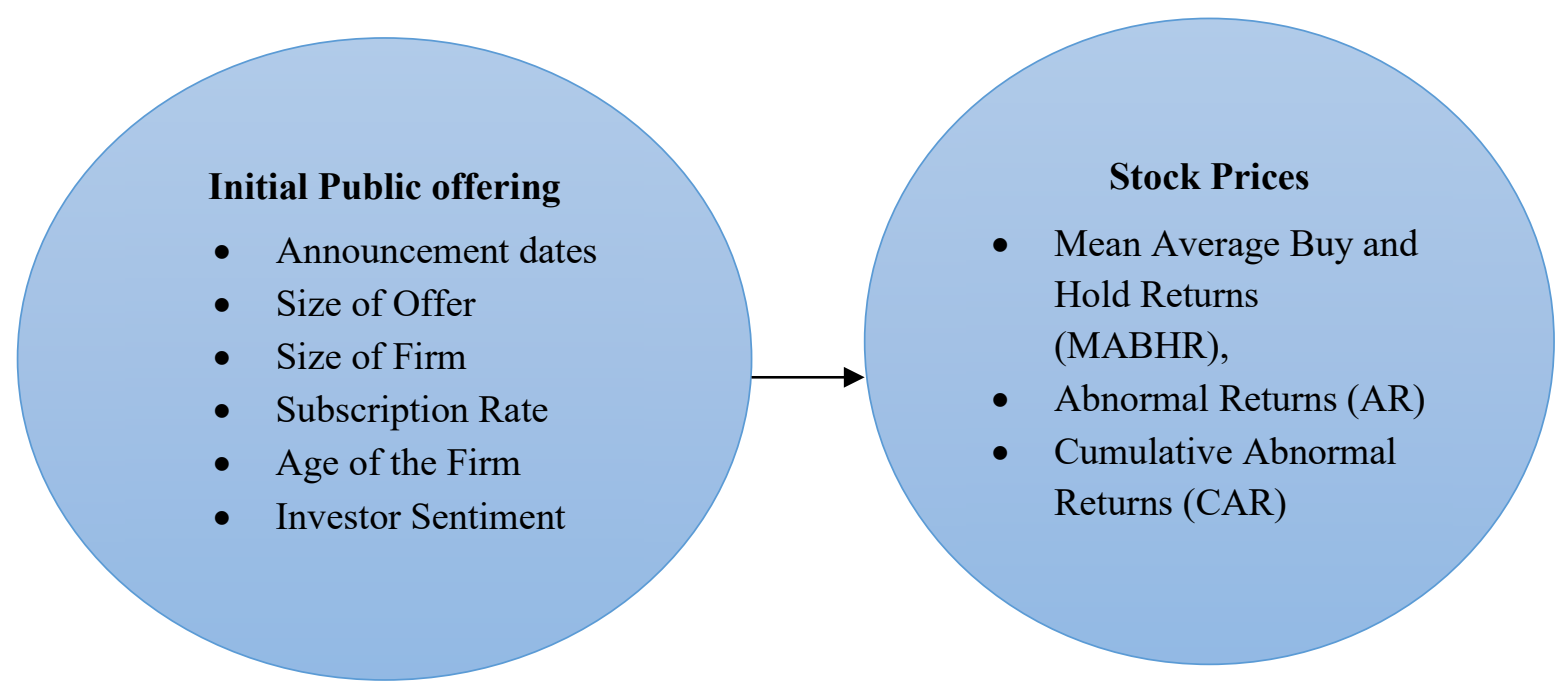

Figure 1. Conceptual framework

\section{Research Methodology}

A descriptive survey research design was was employed in the study. The population of the study encompassed all the sixty-four listed companies at the NSE as at 2016. The study employed a nonprobability purposive sampling technique. The study employed a non-probability purposive sampling technique. Data collected for this study was secondary data obtained from NSE website, NSE price lists and the Central Bank of Kenya website for the period 2007 to 2014. Mean Average Buy and Hold Returns (MABHR), Abnormal Returns (AR) and Cumulative Abnormal Returns (CAR) was used to calculate the performance of the stocks. T-statistic for CAR was computed to the test for its significance. T-test was conducted at 95\% confidence level to find if MABHR and CAR were statistically significant after IPOs announcement.

\section{Data Analysis, and Discussions of Findings}

\subsection{Descriptive Statistics}

The table 1 presents the summary of descriptive statistics of the share price, turnover volume, NSE20 Index, actual return computed from the share prices, market return computed from the NSE-20 Index, the expected returns, the abnormal returns, cumulative abnormal return and MABHR for the companies that offered IPOs between the period 2007 and 2014. 
Table 1. Summary of Descriptive Statistics

\begin{tabular}{lccccc}
\hline Item & $\mathbf{N}$ & Minimum & Maximum & Mean & Std. Dev \\
\hline Share Price & 340 & 1.1 & 34.34 & 10.29394 & 6.824883 \\
Turnover Volume & 340 & 5250 & 72816500 & 4181403 & 10198309 \\
NSE-20 Index & 340 & 2363.99 & 5490.99 & 4080.627 & 736.2868 \\
Actual Return & 340 & -1 & 1.4 & 0.002329 & 0.176054 \\
Market Return & 340 & -1 & 0.4525 & -0.00198 & 0.08841 \\
Expected Return & 340 & -0.953 & 0.7807 & -0.00081 & 0.105393 \\
AR & 340 & -0.3992 & 0.6972 & 0.00244 & 0.132683 \\
CAR & 335 & -1 & 1.4243 & -0.05228 & 0.568783 \\
MABHR & 340 & -0.101 & 0.1438 & 0.002393 & 0.028511 \\
\hline
\end{tabular}

The results indicate that the share price had a mean of 10.29394 with a standard deviation of 6.824883. The means of Turnover Volume was 72816500. The standard deviations from the mean of the Turnover Volume was 10198309. The mean NSE-20 Index was 4080.627 with a standard deviation of 736.2868 . The mean actual return was 0.002329 with the standard deviations of 0.176054 . The mean market return was -0.00198 with the standard deviations of 0.08841 . The mean expected returns for companies was 0.00244 while the deviations from the mean expected returns was 0.105393 . The mean abnormal return was 0.00244 . The standard deviations from the mean abnormal returns was 0.132683 . The results in Table 1 also indicate that the mean cumulative abnormal return was -0.05228 , the standard deviation was 0.568783 while the mean MABHR was 0.002393 with a standard deviation 0.028511 .

\subsection{Determination of Expected and Abnormal Returns}

In order to compute the expected returns and the abnormal returns the regression model of the following form was run:

$A R_{j t}=R_{j t}-E\left(R_{j t}\right)$

Where: $A R_{j t} i s$ abnormal return for security $j$ over time $t, R_{j t}$ is the return of security $j$ at time $t$ and $E\left(R_{j t}\right)$ is the expected return of security $j$ at time $t$.

In order to determine the expected returns $E\left(R_{j t}\right)$, the following market model regression was run:

$$
R_{i t}=\alpha+\beta R m_{i t}+\epsilon_{i t}
$$

Where: $\mathrm{R}_{\mathrm{jt}}$ and $\mathrm{Rm}_{\mathrm{t}}$ are the returns on stock $\mathrm{j}$ and market $\mathrm{m}$ respectively at time period $\mathrm{t}$ and $\epsilon_{\mathrm{it}} \mathrm{is}$ the error term and therefore once the model was run the expected returns $E\left(R_{j t}\right)$, was computed as $E(R)=\left(\alpha+\beta R m_{i t}\right), \alpha$ and $\beta$ are parameters estimated using Ordinary Least Square.

The results presented below shows the alpha $(\alpha)$ and beta $(\beta)$ obtained from the regression model. 
Table 2. Alpha and Beta Coefficients for estimating Expected Returns

\begin{tabular}{llccccc}
\hline Model & & & & & t & Sig. \\
& & B & Std. Error & Beta & & \\
\hline Access & (Constant) & 0.007 & 0.02 & & 0.622 & 0.536 \\
Kenya & Market Return & 1.688 & 0.261 & 0.735 & 8.249 & 0.000 \\
& (Constant) & 0.003 & 0.015 & & -0.145 & 0.885 \\
Kenya Re & Market Return & -0.213 & 0.221 & -0.342 & -2.775 & 0.007 \\
& (Constant) & 0.005 & 0.013 & & 0.401 & 0.690 \\
Safaricom & Market Return & 0.243 & 0.163 & 0.192 & 1.487 & 0.142 \\
& (Constant) & -0.001 & 0.015 & & 0.745 & 0.459 \\
Co-op Bank & Market Return & 1.603 & 0.233 & 0.545 & 4.953 & 0.000 \\
& (Constant) & 0.021 & 0.019 & & 1.251 & 0.216 \\
Britam & Market Return & 1.679 & 0.26 & 0.751 & 8.666 & 0.000 \\
& (Constant) & -0.060 & 0.023 & & -2.649 & 0.012 \\
Home Afrika & Market Return & 0.893 & 0.141 & 0.716 & 6.33 & 0.000 \\
\hline
\end{tabular}

The alpha $(\alpha)$ and beta $(\beta)$ coefficients thus used to estimate the expected returns equation were Access Kenya 0.007 and 1.688, Kenya Re 0.003 and -0.213 , Safaricom 0.005, and 0.243, Co-op Bank -0.001 and 1.1603, Britam 0.021 and 1.679, Home Afrika -0.060 and 0.893 respectively.

After the expected returns had been computed, abnormal returns were also computed using the equation below;

$A R_{i t}=\mathrm{R}_{\mathrm{jt}}-\mathrm{E}\left(\mathrm{R}_{\mathrm{jt}}\right)$

Where $A R_{i t}$ is the abnormal returns and $\mathrm{R}_{\mathrm{jt}}$ is the actual stock returns and $\mathrm{E}\left(\mathrm{R}_{\mathrm{jt}}\right)$ is the computed expected stock returns.

\subsection{Mean Adjusted Buy and Hold Returns}

Table 3 presents a summary of MABHR for each of the IPOs.

Table 3. Summary for MABHR

\begin{tabular}{clcc}
\hline NO. & Company Name & $\begin{array}{c}\text { Short Term } \\
\text { 6 months }\end{array}$ & $\begin{array}{c}\text { Long Term } \\
\text { 60 months }\end{array}$ \\
\hline 1 & Access Kenya Group & $-0.25 \%$ & $-0.13 \%$ \\
2 & Kenya Reinsurance Corporation & $0.01 \%$ & $-0.14 \%$ \\
3 & Safaricom & $0.61 \%$ & $-0.44 \%$ \\
4 & Co-Operative Bank Ltd & $-0.11 \%$ & $0.20 \%$ \\
5 & BRITAM & $1.93 \%$ & $0.40 \%$ \\
6 & Home Afrika & $1.58 \%$ & $1.12 \%$ \\
& Mean & $\mathbf{0 . 6 3 \%}$ & $\mathbf{0 . 1 7 \%}$ \\
& STDEV & $\mathbf{0 . 0 0 9 3}$ & $\mathbf{0 . 0 0 5 0}$ \\
\hline
\end{tabular}

From the Table 3, it is evident that Kenya Reinsurance, Safaricom, BRITAM and Home Afrika over performed the market by $0.01 \% 0.61 \%, 1.93 \%$, and $1.580 \%$ respectively for the 6 months of trading. KENGEN, Access Kenya Group, and Co-Operative Bank Ltd underperformed the market in 6 months of trading by $-0.25 \%$ and $-0.11 \%$ respectively. However, BRITAM over performance was high at $1.930 \%$ in 6 months and Access Kenya Group underperformance was high at $-0.25 \%$. 
Co-Operative Bank Ltd, BRITAM and Home Afrika over performed the market by $0.20 \% 0.40 \%$ and $1.12 \%$ respectively for the long-term months of trading. Access Kenya Group, Kenya RE and Safaricom underperformed the market in 60 months of trading by $-0.13 \%,-0.14 \%$, and $-0.44 \%$ respectively. However, Home Afrika over performance was high at $1.12 \%$ in 40 months and Safaricom underperformance was high at $-0.44 \%$.

\subsection{Cumulative Abnormal Returns}

Table 4 presents a summary of CAR for each of the IPOs

Table 4. Summary for CAR

\begin{tabular}{clcc}
\hline No. & Company & Short Term & Long Term \\
\hline 1 & Access Kenya & $1.46 \%$ & $0.61 \%$ \\
2 & Kenya Re & $-0.11 \%$ & $-0.33 \%$ \\
3 & Safaricom & $-0.51 \%$ & $-1.41 \%$ \\
4 & Co-op Bank & $1.20 \%$ & $1.04 \%$ \\
5 & Britam & $0.10 \%$ & $-1.09 \%$ \\
6 & Home Afrika & $-0.33 \%$ & $-1.76 \%$ \\
& Mean & $\mathbf{0 . 3 0 \%}$ & $\mathbf{- 0 . 4 9 \%}$ \\
& SDV & $\mathbf{0 . 0 0 7 6}$ & $\mathbf{0 . 0 1 0}$ \\
\hline
\end{tabular}

From the Table 4, Access Kenya, Co-Operative Bank Ltd and BRITAM over performed the market by $1.46 \%, 1.20 \%$ and $0.10 \%$ respectively for the 6 months of trading. Kenya Re, Safaricom amd Home Afrika underperformed the market in 6 months of trading by $-0.11 \%,-0.51 \%$ and $-0.33 \%$ respectively. However, Access Kenya over performance was high at $1.146 \%$ in 6 months and Safaricom underperformance was high at $-0.51 \%$

Access Kenya and Co-Operative Bank Ltd over performed the market by $0.61 \%$ and $1.04 \%$ respectively for the 60 months of trading. Kenya Re, Safaricom, BRITAM and Home Afrika underperformed the market in 60 months of trading by $-0.33 \%,-1.41 \%,-1.09$ and $-1.76 \%$ respectively. However, Co-op Bank over performance was high at $1.04 \%$ in 60 months and Safaricom underperformance was high at $-1.41 \%$.

\subsection{Correlation Analysis}

Table 5 presents data and computations for each of the six IPOs individual company's correlations. The study noted that all the company's share price was positively correlated with the market Index. When a share movement is positively correlated with the index, the share is likely to over perform the market. 
Table 5. Correlation Analysis

\begin{tabular}{|c|c|c|c|c|}
\hline Company & & & Share Price & NSE20-INDX \\
\hline \multirow[t]{4}{*}{ Access Kenya } & \multirow[t]{2}{*}{ Share Price } & Pearson Correlation & \multirow{2}{*}{$\begin{array}{r}1.000 \\
\text { Sig. (2-tailed) }\end{array}$} & $.369 * *$ \\
\hline & & & & 0.004 \\
\hline & \multirow[t]{2}{*}{ NSE20-INDX } & Pearson Correlation & $.369^{* *}$ & 1.000 \\
\hline & & Sig. (2-tailed) & 0.004 & \\
\hline \multirow[t]{4}{*}{ Kenya Re } & \multirow[t]{2}{*}{ Share Price } & Pearson Correlation & \multirow{2}{*}{ Sig. (2-tailed) } & $.613 * *$ \\
\hline & & & & 0.000 \\
\hline & \multirow[t]{2}{*}{ NSE20-INDX } & Pearson Correlation & $.613 * *$ & 1.000 \\
\hline & & Sig. (2-tailed) & 0.000 & \\
\hline \multirow[t]{4}{*}{ Safaricom } & \multirow[t]{2}{*}{ Share-Price } & Pearson Correlation & 1.000 & $.731 * *$ \\
\hline & & & Sig. (2-tailed) & 0.000 \\
\hline & \multirow[t]{2}{*}{ NSE20-INDX } & Pearson Correlation & $.731 * *$ & 1.000 \\
\hline & & Sig. (2-tailed) & 0.000 & \\
\hline \multirow[t]{4}{*}{ Co-op Bank } & \multirow[t]{2}{*}{ Share Price } & Pearson Correlation & 1.000 & $.910 * *$ \\
\hline & & & Sig. (2-tailed) & 0.000 \\
\hline & \multirow[t]{2}{*}{ NSE20-INDX } & Pearson Correlation & $.910 * *$ & \multirow[t]{2}{*}{1.000} \\
\hline & & Sig. (2-tailed) & 0.000 & \\
\hline \multirow[t]{4}{*}{ Britam } & \multirow[t]{2}{*}{ Share Price } & Pearson Correlation & 1.000 & $.717 * *$ \\
\hline & & & Sig. (2-tailed) & 0.000 \\
\hline & \multirow[t]{2}{*}{ NSE20-INDX } & Pearson Correlation & $.717^{* *}$ & \multirow[t]{2}{*}{1.000} \\
\hline & & Sig. (2-tailed) & 0.000 & \\
\hline \multirow[t]{5}{*}{ Home Afrika } & \multirow[t]{2}{*}{ Share Price } & Pearson Correlation & \multirow{2}{*}{$\begin{array}{r}1.000 \\
\text { Sig. (2-tailed) }\end{array}$} & $.364 *$ \\
\hline & & & & 0.021 \\
\hline & \multirow[t]{2}{*}{ NSE20-INDX } & Pearson Correlation & $.364^{*}$ & \multirow[t]{2}{*}{1.000} \\
\hline & & Sig. (2-tailed) & 0.021 & \\
\hline & \multicolumn{3}{|c|}{$\begin{array}{l}* * \text { Correlation is significant at the } 0.01 \text { level (2-tailed). } \\
* \text { Correlation is significant at the } 0.05 \text { level (2-tailed). }\end{array}$} & \\
\hline
\end{tabular}

\subsection{Test of Significance}

A t-test was conducted at $95 \%$ confidence level to find if there was a significant relation between the short term and long term MABHR and CAR after IPOs announcement. Short term is the analysis of the first six months after the IPOs announcement days while the long run is the sixty months' analysis and 40 months for Home Afrika. Table 6 shows the results from the analysis. 
Table 6. Summary Test of Significance

\begin{tabular}{|c|c|c|c|c|c|c|}
\hline Company & & Period & Mean & $\begin{array}{l}\text { Std. } \\
\text { Dev }\end{array}$ & $\begin{array}{l}\text { Std. Err } \\
\text { Mean }\end{array}$ & t-statistic \\
\hline \multirow[t]{4}{*}{$\begin{array}{l}\text { Access } \\
\text { Kenya }\end{array}$} & MABHR & Short term & -0.002 & 0.024 & 0.010 & \\
\hline & & Long term & -0.001 & 0.030 & 0.004 & $\mathrm{t}=-0.093(\mathrm{p}=0.5700)$ \\
\hline & CAR & Short term & 0.235 & 0.104 & 0.042 & \\
\hline & & Long term & 0.566 & 0.615 & 0.084 & $\mathrm{t}=-3.508(\mathrm{p}=0.001)$ \\
\hline \multirow[t]{4}{*}{ Kenya Re } & MABHR & Short term & 0.000 & 0.001 & 0.000 & \\
\hline & & Long term & -0.001 & 0.024 & 0.003 & $\mathrm{t}=2.43(\mathrm{p}=0.049)$ \\
\hline & CAR & Short term & -0.061 & 0.066 & 0.027 & \\
\hline & & Long term & -0.273 & 0.214 & 0.029 & $\mathrm{t}=2.531(\mathrm{p}=0.010)$ \\
\hline \multirow[t]{4}{*}{ Safaricom } & MABHR & Short term & 0.006 & 0.004 & 0.002 & \\
\hline & & Long term & -0.004 & 0.023 & 0.003 & $\mathrm{t}=1.088(\mathrm{p}=0.058)$ \\
\hline & CAR & Short term & -0.385 & 0.155 & 0.063 & \\
\hline & & Long term & -0.354 & 0.237 & 0.033 & $\mathrm{t}=-1.312(\mathrm{p}=0.124)$ \\
\hline \multicolumn{7}{|l|}{ Co-op } \\
\hline \multirow{3}{*}{ Bank } & & Long term & 0.002 & 0.021 & 0.003 & $\mathrm{t}=-0.312(\mathrm{p}=0.379)$ \\
\hline & CAR & Short term & 0.200 & 0.447 & 0.200 & \\
\hline & & Long term & 0.370 & 0.487 & 0.066 & $\mathrm{t}=-2.809(\mathrm{p}=0.030)$ \\
\hline \multirow[t]{4}{*}{ Britam } & MABHR & Short term & 0.019 & 0.027 & 0.011 & \\
\hline & & Long term & 0.004 & 0.023 & 0.003 & $\mathrm{t}=1.512(\mathrm{p}=0.806)$ \\
\hline & CAR & Short term & 0.000 & 0.000 & 0.000 & \\
\hline & & Long term & -0.151 & 0.361 & 0.050 & $t=3.04(p=0.017)$ \\
\hline \multicolumn{6}{|l|}{ Home } & \\
\hline \multirow{3}{*}{ Afrika } & & Long term & 0.011 & 0.044 & 0.007 & $\mathrm{t}=1.364(\mathrm{p}=0.278)$ \\
\hline & CAR & Short term & -0.833 & 0.408 & 0.167 & \\
\hline & & Long term & -0.618 & 0.493 & 0.085 & $\mathrm{t}=-2.154(\mathrm{p}=0.005)$ \\
\hline
\end{tabular}

Table 6 shows the MABHR t-test analysis on the short-term and long-term. The results show that there was a significant difference on MABHR and CAR short term and long term comparison. MABHR had an insignificant relation in all the companies except for Kenya Re where there is a significate relation in t-test between the short-term and long-term analysis. CAR has a significant ttest relation for all the companies except Safaricom where there is insignificant relation between the short term and the long term 


\section{Conclusions}

Using MABHR methodology IPOs over performed the market by $0.17 \%$ while using CAR methodology IPOs underperformed the market by $0.49 \%$. Adverse under performance causes considerable uncertainty to investors bearing in mind that under IPO, firms use their prospectus to invest heavily in their companies. The study agrees with the assertion by [12] and [59] that all the IPOs underperform the market in the long run using CAR methodology.

The study concludes that the number of shares issued influences the long run performance of shares in the long run, whereby an increase in the number of shares issued reduce the performance of shares in the long run while a decrease in the number of shares issued increases the performance of shares. The study finally concludes that the percentage subscription affects the performance of shares of a company in the long run. Increased percentage of subscription increase the performance of shares in the long run while decreased in subscription rate reduces the performance of shares in the long run.

\section{Recommendations}

Based on these findings, the study recommends for the implementation of policies by the NSE management so as to have a consistent situation. The firms should also put in place measures to ensure continued performance of their shares in the long run. The study recommends for policies to be enacted regulating the number of shares being issued by firms. The study findings established that that size of a firm affects the performance of shares of that firm the long run. Based on this finding, this study recommends that firms listed at the NSF need to put in place strategies that will ensure their continued expansion as this is important for ensuring enhanced performance of shares in the long run.

\section{References}

[1] Rajagopalan, A. A. (2013). Speculative Initial Public Offerings A Disagreement Approach to the IPO Puzzle. Princeton: Princeton University Press.

[2] Braun, M., \& Larrain, B. (2005). Finance and the business cycle: international, inter-industry evidence. The Journal of Finance, 60(3), 1097-1128.

[3] Maksimovic, V., \& Pichler, P. (2001). Technological innovation and initial public offerings. The Review of Financial Studies, 14(2), 459-494.

[4] Horne, J. C. V., \& Parker, G. G. C. (1967). The Random Walk Hypothesis. Financial Analyst Journal, 23 (6), 87-92.

[5] Fama, E. F. (1965). The behavior of stock-market prices. The journal of Business, 38(1), 34105.

[6] Tsangarakis, N. V. (2004). The Price Performance of Initial Public Offerings in Greece.Managerial Finance, 30(10), 26-44.

[7] Edmonston, P. (2009). Google's I.P.O., five years later -NYTimes.com. Dealbook.nytimes.com. Retrieved on 2020-10-16.

[8] Bante, A. H. (2010). A comparative evaluation of the performance of initial public offerings of private and state owned companies at the Nairobi Stock Exchange (Doctoral dissertation, University of Nairobi, Kenya).

[9] Peng, L. (2005). The Initial Performance of IPOs: Further Evidence from Bursa Malaysia. Journal of Finance, 144 (4), 297-402.

[10] Durukan, M., \& Yerleskesi, K. (2002). The Relationship Between IPO Returns and Factors Influencing IPO Performance: Case of Istanbul Stock Exchange. Managerial Finance, 28(2), 18-38. 
[11] Agarwal, S., Liu, C., \& Rhee, S. G. (2008). Investor demand for IPOs and aftermarket performance: Evidence from the Hong Kong stock market. Journal of International Financial Markets, Institutions and Money, 18(2), 176-190.

[12] Kahneman, D., \& Tversky, A. (1980). Prospect theory. Econometrica, 12. Accessed at oer2go.org on $22^{\text {nd }}$ January 2021.

[13] Ma, T., \& Shen, Y. (2003). Prospect theory and the long-run performance of IPO stocks. Available at SSRN 488146.

[14] Mutai, J. (2019). Effects of firm characteristics on the post-IPO performance by listed companies on the Nairobi Securities Exchange (NSE), Kenya. African Journal of Education, Science and Technology, 5(3), 160-170.

[15] Fama, E. (1970). Efficient capital markets: A review of theory and empirical work. Journal of Finance, 25(2), 383-417.

[16] Koech, C. C. (2011). Short-run and long-run ipo financial performance for firms quoted at the nairobi stock exchange (Doctoral dissertation).

[17] Jumba, W. N. (2002). Initial public offer performance in Kenya (Doctoral dissertation, University of Nairobi).

[18] Nabucha S.. (2008). Pricing and performance of Initial Public Offering (IPO): A comparison between State Owned Enterprises and Privately Owned Enterprises at the NSE. (Unpublished MBA project. University of Nairobi).

[19] Ndatimana, E. (2008). Performance of Initial Public Offerings: The Evidence from Nairobi Stock Exchange (Doctoral dissertation, University Of Nairobi).

[20] Rock, K. (1986). Why new issues are underpriced, Journal of Financial Economics 15(1-2), 187-212.

[21] Chorruk, I., \& Worthington, A. (2010). New evidence on the pricing and performance of initial public offerings in Thailand. Emerging Markets Review, 11(13), 285-299.

[22] Vong, A., \& Trigueiros, D. (2010). The short-run price performance of initial public offerings in Hong Kong: New evidence. Global Finance Journal, 21(3), 253-261.

[23] Chan, K., Wang, J., \& Wei, K. J. (2004). Underpricing and long-term performance of IPOs in China. Journal of Corporate Finance, 10(3), 409-430.

[24] Ritter, J. R. (1991). The long-run performance of initial public offerings. The journal of finance, 46(1), 3-27.

[25] Loughran, T., \& Ritter, J. R. (1995). The new issues puzzle. The Journal of finance, 50(1), 2351.

[26] Chia, J., \& Padgett, C. (2005). Short-run underpricing and its characteristics in Chinese initial public offering (IPO) markets. Research in International Business and Finance, 19(1), 71-93.

[27] Li, M., Zheng, S. X., \& Melancon, M. V. (2005). Underpricing, share retention, and the IPO aftermarket liquidity. International Journal of Managerial Finance. 1(2), 76-94.

[28] Ritter, J. R., \& Welch, I. (2002). A review of IPO activity, pricing, and allocations. The journal of Finance, 57(4), 1795-1828.

[29] Agathee, U. S., Sannassee, R. V., \& Brooks, C. (2012). The underpricing of IPOs on the stock exchange of Mauritius. Research in International Business and Finance, 26(2), 281-303.

[30] Kanja, J. N. (2014). The effect of initial public offerings on the stock returns of companies listed at the Nairobi securities exchange (Doctoral dissertation, University of Nairobi). 
[31] Kyaka, J., M. (2010). An assessment of the relative importance of the factors influencing decision-making in initial public offerings (IPOs) in Kenya. (Unpublished MBA Project, University of Nairobi).

[32] Wachira, J.A. (2012). A survey of the determinants of the success of initial public offering (IPOs) among the companies listed at the NSE. (Unpublished MBA Project, University; of Nairobi).

[33] Simiyu, E. N. (2008). Pricing and performance of Initial Public Offering (IPO): $A$ comparison between state owned enterprises and privately owned enterprises at the NSE (Doctoral dissertation, University of Nairobi).

[34] Leshore, P., K. (2012). Medium-term performance of the initial public offering at Nairobi stock exchange. (Unpublished MBA Project, University of Nairobi).

[35] Sharma, G. D., \& Mahendru, M. (2009). Efficiency hypothesis of the stock markets: a case of Indian securities. International Journal of Business and Management, Available at SSRN: https://ssrn.com/abstract=1827522.

[36] Shostak, F. (1997). In Defence of Fundamental Analysis: A Critique of EMH. Review of Australian Economics, 10(2), 27-45.

[37] Seneque, P. J. C. (1979). The Relationship between Portfolio Theory and the Efficient Market Hypothesis. The Investment Analyst Journal, 8(13), 17-21.

[38] Lo, A. W., MacKinlay, A. C., \& Zhang, J. (2002). Econometric models of limit-order executions. Journal of Financial Economics, 65(1), 31-71.

[39] Loughran, T., \& Ritter, J. R. (2002). Why don't issuers get upset about leaving money on the table in IPOs?. The Review of Financial Studies, 15(2), 413-444.

[40] Ljungqvist, A. P., \& Wilhelm, W.J. (2003) What makes issuers happy? Testing the Prospect Theory of IPO Underpricing. Working paper series, New York University.

[41] Akerlof, G. (1970). The market for lemons: Quality uncertainty and the market mechanism. The Quarterly Journal of Economics, 89, 488-500.

[42] Beatty, R. P. (1989). Auditor reputation and the pricing of initial public offerings. Accounting Review, 6494), 693-709.

[43] M'kombe, C., \& Ward, M. (2002). Aftermarket price performance of initial public offerings on the JSE. Investment Analysts Journal, 31(55), 7-20.

[44] Kiran, R., \& Phil, R. (2011). Price performance of IPOS in Indian stock market.Euroeconomica, 4(30), 73-97.

[45] Zaluki, N., \& Kect, L. (2012).The Investment Performance of Mesdaq Market Initial Public Offerings (IPOs). Asian Academy of Management. Journal of Accounting and Finance, 8(1),1-23.

[46] Megginson, W. L., \& Weiss, K. A. (1991). Venture capitalist certification in initial public offerings. The Journal of Finance, 46(3), 879-903.

[47] Osei, K. A., Adjasi, C. K., \& Fiawoyife, E. U. (2012). Underpricing of initial public offerings on African stock markets: Ghana and Nigeria. AERC.

[48] Daily, C. M., Certo, S. T., Dalton, D. R., \& Roengpitya, R. (2003). IPO underpricing: A meta-analysis and research synthesis. Entrepreneurship Theory and Practice, 27(3), 271-295.

[49] Yong, O. (2011). Winner's curse and bandwagon effect in Malaysian IPOs: Evidence from 2001-2009. Jurnal Pengurusan (UKM Journal of Management), 32(2011) 21-26.

[50] Cheluget K. J L. (2008) Investor Demand for IPO's and first day performance: Evidence from Nairobi Stock Exchange. (Unpublished MBA project, University of Nairobi). 
[51] Bansal, R., \& Khanna, A. (2012). Determinants of IPOs initial return: Extreme analysis of Indian market. Journal of financial risk management, 1(04), 68-74.

[52] Booth, J. R., \& Chua, L. (1996). Ownership dispersion, costly information, and IPO underpricing. Journal of financial economics, 41(2), 291-310.

[53] Carter, R., B. (1998). Underwriter Reputation, Initial Returns and the Long-run Performance of IPO Stocks, Journal of Finance, 53(1), 285-311.

[54] Ritter, J. R. (1984). The" hot issue" market of 1980. Journal of Business, 57(2), 215-240.

[55] Baker, M., \& Wurgler, J. (2007). Investor Sentiment in the Stock Market, Journal of Economic Perspective, 21(2), 129-151.

[56] Cornelli, F., Goldreich, D., \& Ljungqvist, A. (2006). Investor sentiment and pre-IPO markets. The Journal of Finance, 61(3), 1187-1216.

[57] Barberis, N., Shleifer, A., \& Vishny, R. (1998). A model of investor sentiment. Journal of financial economics, 49(3), 307-343.

[58] Brown, G. W., \& Cliff, M. T. (2005). Investor sentiment and asset valuation. The Journal of Business, 78(2), 405-440.

[59] Njoroge M.. (2004). An analysis of Performance of Initial Public Offerings, a case of Nairobi Stock Exchange. (Unpublished MBA project, University of Nairobi). 